\title{
The Europe Africa Conference 2017 of the POLYMER PROCESSING SOCIETY（PPS）報告
}

\section{1.はじめに}

Polymer Processing Societyは，プラスチック成形加工 に関する研究成果の発表と議論の場を提供することを目的 として 1985 年に設立され，1995 年に第 1 回会議がアメリ カ・アケロンで開催された. ドイッ・ザクセン州の首都ド レスデンにおいて 6 月 26 日〜29日に開催された「PPS ヨーロッパ・アフリカ地域会議 2017 (PPS 2017)」は, 地 域会議としては 1996 年以来であった. ドレスデン市は, ドイツの高分子科学をはじめとする材料科学の中心地であ るばかりでなく, 文化的なスポットでもあり, 世界的に有 名な博物館が数多くある．災害が少ないためか，歴史的な 街並みがいくつか現存していた．特にドレスデン駅 (図 1) は，日本では強度不足だと感じられるようなシンプルな アーチ状のガラス張り構造であったが, 非常に美しい外観 であった.

会議はドイツ衛生博物館（図 2）で行われ，会場と高分 子との繋がりは「Woman of glass」と呼ばれる透明な人 体模型の展示品にあるとの紹介がなされた。「Woman of glass」は 1935 年に創作され, セロン（可塑剤として樟脳

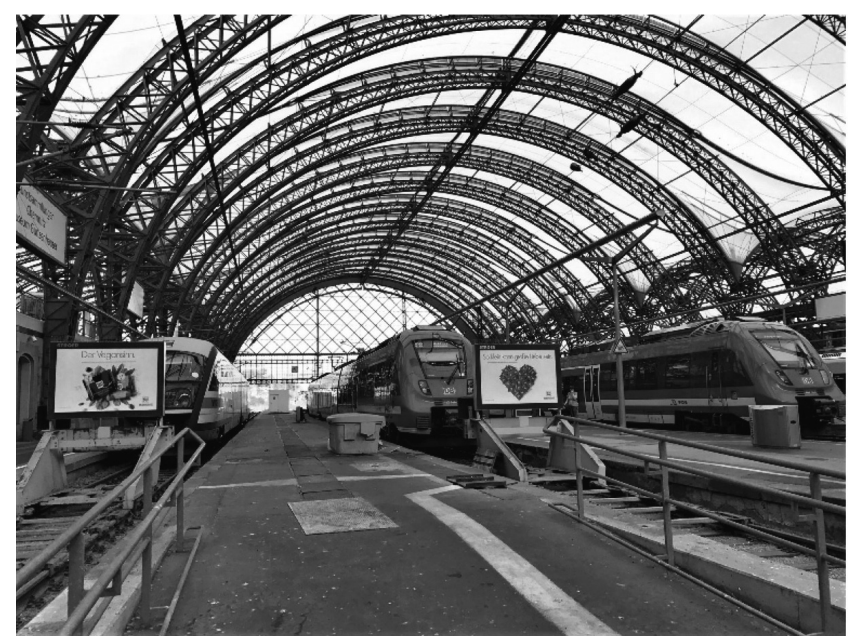

図 1 ドレスデン駅

\footnotetext{
* Ishigami, Akira

山形大学・工学部技術部

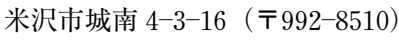

akira.ishigami@yz.yamagata-u.ac.jp 2017.9.11受理
}

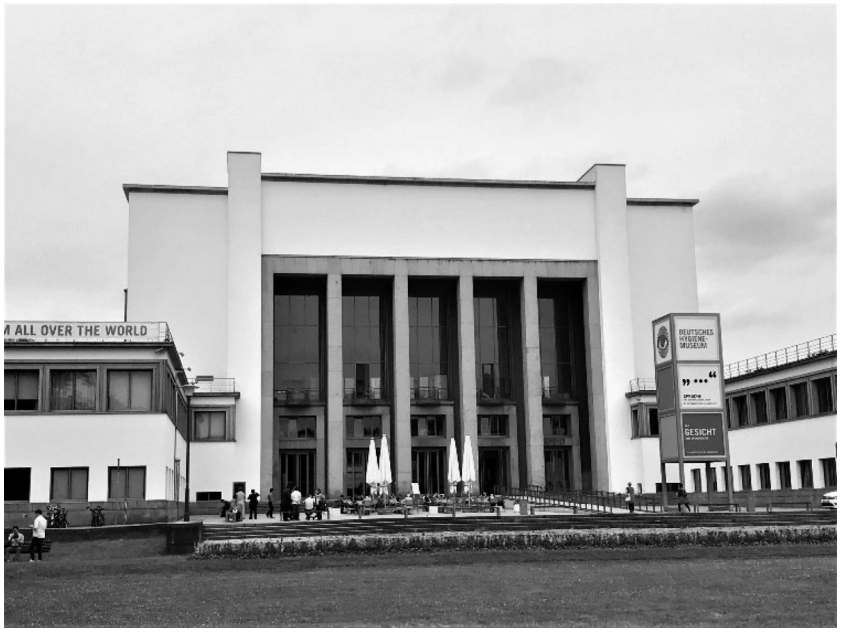

図 2 会場のドイツ衛生博物館

を使用したセルロースアセテート）を大量に用いた作品で あり，当時はセンセーショナルな作品であったとのことで ある。

\section{2. 会議内容}

会議は 14 のセッションにおいて 322 件の口頭発表，そ して 118 件のポスター発表が行われた。参加者は 500 名以 上との報告があり，おおいに盛況であった（図 3). 参加 者のうち日本人は 20 名程度であった. 同時開催の特別シ ンポジウムとして CNPComp 2017（7th International Con-

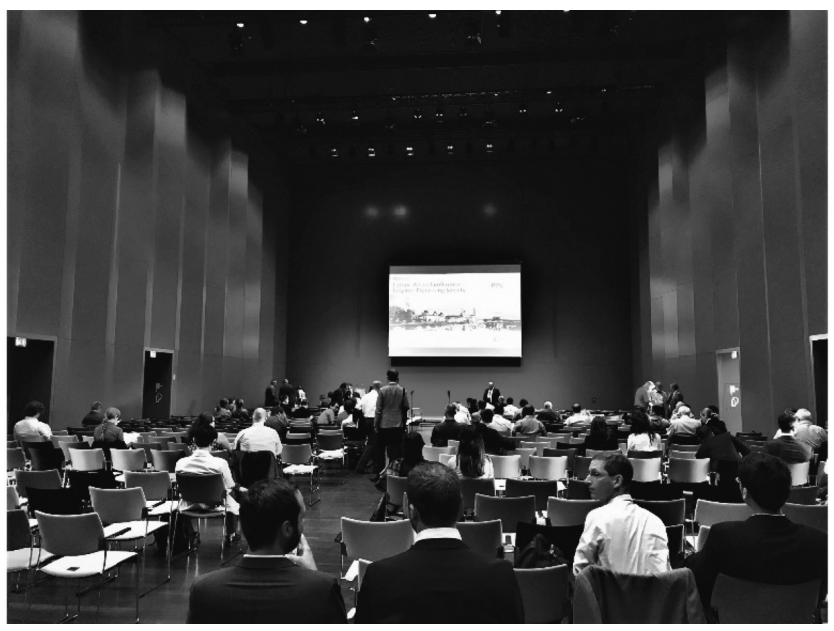

図 3 口頭発表会場の様子 
ference on Carbon NanoParticle Based COMPosites) が 開催されており, 研究発表テーマとしても炭素粒子や機能 性フィラーとポリマーの複合材料化に関する研究発表が多 数行われていた.

筆者らが聴講した講演の一部を簡単に紹介する. Mixing and Compounding のセッションにおいて, マサチューセッ ツ大学ローウェル校の Sobkowicz らは高速二軸混練押出 機を用いたリアクティブポリマーブレンドにおける樹脂分 解について報告した. Poly (propylene carbonate) (PPC) /Poly (butylene succinate) (PBS) ブレンドを $4000 \mathrm{rpm}$ までの速度で混練し, 分子鎖切断と固有のせん断粘弾性挙 動の関係を流体力学シミュレーションと反応速度論を組み 合わせてモデル化したという発表であった。このセッショ ンでは，他の多くのテーマにおいて実験とシミュレーショ ンを併用しており, 溶融混練の原理的な理解を深める研究 が特に進んでいると感じられた。

Polymer Blends and Alloys のセッションにおいて, 国 立成功大学の Chen らは Poly (vinylmethylether) (PVME) /Poly (3-hydroxybutyrate-co-3-hydroxyvalerate) (PHBV) ブレンドの球晶の層状集合体形成メカニズムについて報告 した。異なる温度での PHBV 結晶の成長挙動を観察・分 析した. 球晶成長状態および層状集合体構造形成過程が偏 光顕微鏡 $(\mathrm{POM})$ および走査電子顕微鏡 $(\mathrm{SEM})$ を用い て詳細に分析されており, 非常に興味深い内容であった.

特別セッションである CNPComp 2017 では, Wallen- berg Wood Science Center の Mianehow らはグラフェン およびセルロースナノファイバー (CNF) の表面処理に より改質し，ポリマーとの複合材料化による機械的特性へ の影響を報告した.グラフェンの親水性誘導体である酸化 グラフェンを CNF と同時にポリマーヘブレンドすること で, CNF および酸化グラフェンの分散性が CNF 単体ブレ ンドよりも向上することを見出した. 微分散化およびナノ コンポジット化によって CNF 単体ブレンドの弾性率が $9.3 \mathrm{GPa}$ であるのに対して, $\mathrm{CNF} /$ 酸化グラフェンブレン ドの弾性率が $16 \mathrm{GPa}$ に達するとのことであった。

\section{3.おわりに}

ポリマーブレンドおよびコンポジットの発表を通して， ナノスケールでの微細分散構造制御に関する研究が多数見 受けられた。そのうえで, CAEを含むシミュレーション を併用して，樹脂/樹脂分散や樹脂/フィラー分散の過程解 析や繊維配向を理論的に整理し，モデル化する試みが積極 的に行われていた。当然ながら，射出成形や樹脂溶融体の 流動解析シミュレーションも行われているが，近年の計算 機の能力向上や計算手法の研究の進渉によって, 計算結果 の精度が飛躍的に向上してきていると感じられた。

人工知能 $(\mathrm{AI})$ に関するニュースが世間を賑わせてい るが，成形加工の分野においても計算科学と実験の融合に 基づいたブレイクスルーが期待されるような発表の多い国 際会議であった。 